\title{
China's Approaches to the South China Sea Code of Conduct Negotiation
}

\author{
ZHANG Feng*
}

China is pressing ahead with the negotiation on a code of conduct (COC) in the South China Sea with remarkable resolve. The new COC-centred diplomacy was motivated to suppress the impact of the Philippines versus

China arbitral ruling, de-escalate regional tension and promote cooperation, especially the Belt and Road Initiative. It also serves as a broad strategic goal, i.e. preserving stability by banishing the ruling and creating a new diplomatic process with China exercising some control.

WHILE CHINA IS busy negotiating on a code of conduct (COC) with claimant states in the South China Sea issue, it is also building islands at a steady pace. If island-building marks the iron fist of Chinese security policy, COC negotiation

* Zhan8 Fen8 is Senior Lecturer at the Department of International Relations, Australian National University's Coral Bell School of Asia Pacific Affairs, and Adjunct Professor at the National Institute for South China Sea Studies in China. Hewas Visitin\& Senior Research Fellow at the East Asian Institute, National University of Singapore. 
represents the velvet glove of its diplomacy. Since 2016 China's resolve to press ahead with the COC negotiation has been striking, especially compared with its earlier lethargy.

\section{Code of Conduct Negotiations}

China and ASEAN (Association of Southeast Asian Nations) countries first agreed to begin COC consultation in September 2013. Hardly had the process gotten under way when it was disrupted by Beijing's island-building, which started around the same time. The lack of policy coordination between the Ministry of Foreign Affairs (MFA) and the People's Liberation Army (PLA) Navy, which was responsible for the island-building, is evident.

In August 2016, however, China picked up the slack and agreed with ASEAN countries to expedite the COC For Beijing, consultation. In August 2017, both parties agreed on

it had staked out a firm position of "four nos"no participation,

no acceptance, no recognition and no enforcement. a framework text for the COC. In November 2017, they formally launched negotiation. In August 2018, a single text for negotiation was finalised. Three months thereafter, during the November 2018 China-ASEAN leaders' summit, Premier Li Keqiang announced China's intention to complete the COC consultation in three years.

This brisk pace contrasted with its lethargy in 1992 when ASEAN suggested a quest for a code of conduct in the South China Sea. China agreed to the task in 1999. However, instead of a code, major differences among the parties compelled a compromise outcome in the form of the Declaration on the Conduct of Parties (DOC) signed in 2002 .

\section{A Necessary Tactic}

The decision to expedite the COC consultation in August 2016 followed directly from the release of, one month earlier, a ruling by an international arbitral tribunal on the Philippines versus China disputes in the South China Sea. An overwhelming victory for the Philippines and a hefty defeat for China, the ruling drastically reduced China's maritime rights in the Spratlys and Scarborough Shoal.

For Beijing, it had staked out a firm position of "four nos"-no participation, no acceptance, no recognition and no enforcement. It scrambled to control the ruling's impact, especially to prevent it from being accepted and implemented by regional countries. China was enraged by what it saw as an extremely biased ruling. It nevertheless contained its fury to maintain regional stability. Tension was already running high due to regional and US responses to China's islandbuilding and China's attack on the arbitration. By this time, Beijing had realised that maritime tensions were hurting its overall foreign policy interests. This was a trend to reverse, especially now that promoting the Belt and Road Initiative 
(BRI) had become a central task of its Southeast Asia policy. The need to suppress the ruling, de-escalate regional tension and promote BRI produced China's new COC-centred diplomacy.

COC negotiation was thus Beijing's proactive attempt to seize the negative occasion of the release of the arbitral ruling and turn it into a positive opportunity. It arose out of careful calculation. "It is time", said an MFA official when describing the ministry's thinking at the time, "to unleash the COC process."

\section{Counteracting the Philippines Versus ChinaArbitral Ruling}

Chinese experts have recognised that the key decisions in the ruling - especially the annulment of China's historic rights based on its "nine-dash line" which intrudes into the exclusive economic zone of other coastal states and the rejection of the entitlement of all the disputed "islands" as defined by the United Nations Convention on the Law of the Sea-are likely to be exploited as leverage by Southeast Asian claimant states.

To pre-empt such moves, the experts suggest that instead of preventing these countries from citing the ruling, China should shift to a proactive gear and advance negotiation positions that at once meet international legal standards and the "comfort levels" of all the parties. ${ }^{2}$ Yet they have so far advanced little in the way of feasible proposals to this effect, especially when it comes to the legal requirement.

One scholar suggested that China should insist on the vaguely worded "the South China Sea region" as the geographical area to which the COC should apply, in order to maintain the status quo of the disputes. It should promote maritime cooperation including joint development of resources, an area neglected in the DOC, and foster multilateral cooperation by means of bilateral cooperation with ASEAN countries. None of these suggestions venture to the legal domain and are thus unlikely to meet the expectations of key Southeast Asian claimant states, especially Vietnam.

\section{The Stability-Rights Balance}

The motivation of smothering the impact of the arbitral ruling points to a broad strategic goal which the COC negotiation is tasked to serve-preserving stability by banishing the ruling and creating a new diplomatic process over which China can exercise some control. As an MFA official remarked, among all the parties to the South China Sea disputes, China is the biggest victim of regional instability. Instability opens cracks for "extra-regional countries"-above all the United States - to intervene and counteract Chinese policies. Simultaneously it gives

\footnotetext{
${ }^{1}$ Author's interview with an MFA official, Beijing, September 2016.

${ }^{2}$ Yan Yan, "Nanhai xingwei zhunze' lishi huigu ji anwen cuoshang qianjing zhanwang" (A Historical Review of the "Code of Conduct in the South China Sea" and the Prospect of Draft Text Negotiation), Nanhai pinglun (South China Sea Review), no. 2, September 2018, pp. 85101, at p. 97.
} 
opportunities to "reckless" claimant states such as Vietnam for seeking support from outside intervention.

The goal of maintaining stability helps to explain why China insists on the $\mathrm{COC}$ as a mechanism for building confidence, managing incidents and facilitating cooperation rather than one for settling territorial disputes or delimiting maritime interests. Thus, according to the version of the single draft negotiating text obtained by Carlyle Thayer, the "general provisions" of the text describe the COC's objectives as:

(i) To establish a rules-based framework containing a set of norms to guide the conduct of parties and promote maritime cooperation in the South China Sea;

(ii) To promote mutual trust, cooperation and confidence, prevent incidents, manage incidents as they occur and create a favourable environment for the peaceful settlement of the disputes; and

(iii) To ensure maritime security and safety, and freedom of navigation and overflight. ${ }^{3}$

China has recognised the significance of rules in regional order-building. Major speeches by President Xi Jinping and Premier Li Keqiang at the end of 2018 had conspicuously added support for "rules" (guize) as China's policy principles. ${ }^{4}$ In the COC negotiation, it has endorsed the langue of a "rules-based" order. However, these rules are seemingly behavioural norms for guiding national policy rather than legal mechanisms for settling territorial and maritime disputes. When disputes arise, the norms are supposed to contain and manage by prescribing a set of behavioural rules for the conduct of the parties.

The Chinese position is to settle disputes bilaterally between the disputant parties and the function of regional rules and norms such as the COC is to create "a favourable environment for the peaceful settlement of the disputes". This position may not be far-reaching, but it is not unreasonable. It suggests a normsbased approach to regional order-building, putting the COC at the centre of the emerging order. Norms, along with other institutions, have been central to the international order. In part for this reason, ASEAN countries are in agreement, so are international experts, even if reluctantly.

The MFA, as a whole, has been more attentive to regional stability than the PLA, which is geared towards protecting and expanding perceived Chinese rights.

\footnotetext{
${ }^{3}$ Carlyle A Thayer, "From Confidence Building, Preventive Diplomacy and Dispute Resolution to the ASEAN-China South China Sea Code of Conduct", paper presented to the 10th South China Sea International Conference, Da Nang, Vietnam, 7-9 November 2018, pp. 1-22, at p. 11. ${ }^{4}$ See, for example, Xi Jinping, "Tongzhou gongji chuangzao meihao weilai" (Working Together to Create a Splendid Future), Port Moresby, 17 November 2018, <http://jhsjk.people.cn/ article/ 30406666? isindex=1> (accessed 19 February 2019).; and Li Keqiang, "Zai di ershiyici Zhongguo-Dongmeng lingdaoren huiyi shang de jianghua" (Remarks at the 21st China-ASEAN Leaders' Summit), 14 November 2018, Singapore, <http://cpc.people.com.cn/n1/2018/1115/ c64094-30401419.html> (accessed 19 February 2019).
} 
The mismatch between the priorities of the MFA and the PLA can be explained by their institutional settings, although their differences should not be exaggerated. Stability is not the MFA's only goal.

Institutionally, the MFA is set up for diplomacy, but under the overall framework of national strategy. China's strategy in the South China Sea calls for safeguarding rights (wei quan) and maintaining stability (wei wen) at the same time. The COC negotiation not only serves the useful function of leading a new diplomatic process after the arbitral ruling, but also affords a cost-effective means for consolidating strategic gains made by island-building.

The MFA was not happy with being shut out of the initial island-building decision-making process and having to mop up the international backlash thereafter. It nevertheless succeeded in containing the backlash and entrenching the fait accompli, an accomplishment it may justly be proud of.

COC negotiation is thus not an instance of the MFA's one-sided prioritisation of stability over rights, but an attempt to achieve a balance between stability and rights. It is a tactical move with strategic significance. The move also signals a larger shift in China's South China Sea strategy, from driving for lopsided gains of either stability or rights, an all too common aim before 2016, to achieving a dynamic balance between stability and rights.

In fact, Xi had outlined such an approach in July 2013 at a Chinese Communist Party Politburo collective study session. He outlined a sort of dialectics between the goals of rights and stability, emphasising the need to "coordinate the two overall situations of maintaining stability and safeguarding rights". It took the "unleashing of the COC"- and more than three years-for China to achieve this balance with some success. In this sense, the COC negotiation stands out as a touchstone for China's larger strategy in the South China Sea.

\section{The Three-year Timetable}

That China proposed a timetable of three years for completing the COC negotiation might seem surprising at first. Since the 1990s, when such a negotiation was first mooted and prodded by ASEAN, China had stalled for time. Its reluctance arose from the fear of being bound by a code too early and too cumbersomely.

Beijing understood that it was not only the small states of Southeast Asia that wanted to constrain its freedom of action, but also the United States, whose supposedly nefarious designs always loomed large in Chinese deliberations, and which has also wanted to have China boxed in, ideally with a legally binding 
code. What these countries wanted so badly China must not give away too easily, so the thinking went at the time.

ASEAN countries, for their part, had blamed China for the slow progress in upgrading the DOC into a COC, suspecting a deliberate stalling tactic. Many believe that time is on China's side. Since 2012 China has steadily expanded its presence in the South China Sea, including wresting control of Scarborough Shoal from the Philippines and building islands for military-civil dual purposes. The fear is that the longer the COC negotiations take, the more advantageous China's position - and thus the more perilous the positions of Southeast Asian countries-will become. China can use the period of negotiation to consolidate its security gains and expand control over the resources of the South China Sea, including fisheries and hydrocarbon resources.

Doubtless many Chinese elites concur with such assessments. However, events after July 2016 informed China of the contrary. The arbitral ruling has transformed

America's freedom of navigation operations (FONOPs)

created a new security risk, now exacerbated by the assertiveness of the Donald Trump administration. the international legal framework of South China Sea disputes. America's freedom of navigation operations (FONOPs) created a new security risk, now exacerbated by the assertiveness of the Donald Trump administration. Military patrol against Chinese features in the South China Sea has also been internationalised: the naval forces of Japan, Australia, France, Britain and South Korea have all entered the fray. Although these countries have tried in various ways to differentiate their actions from US-style FONOP, they are united in contesting perceived excesses in China's maritime claims.

These legal and security developments have created new uncertainties and China can no longer take stability in the South China Sea for granted. There is a sense of urgency on the part of MFA officials to reduce volatility and consolidate stability. They have thus gravitated towards a timetable for COC negotiation.

As long as such a timetable can help to facilitate negotiation, reduce uncertainty and stabilise the region, it will be in China's interest. At the very least, the threeyear timetable can demonstrate China's commitment to a COC and thus reduce foreign criticisms of China's supposed disregard for the rules-based order in the South China Sea. Along with the overall negotiation process, the timetable is meant to serve as a stabiliser for the South China Sea.

The new thinking has also turned around the earlier fear of being bound by the COC in China's head: constraining China is by no means the only possible effect of the COC; China can proactively use the COC to its own advantage and lead, if not dominate, multilateral diplomacy in the South China Sea. 
There are, of course, practical considerations in proposing a three-year timetable from 2019 to 2021. In October 2018, one month before Premier Li's formal announcement, Foreign Minister Wang Yi had hinted at such a timetable at a press conference in Manila. He said that China expected to complete the COC consultation during the Philippines' tenure as the coordinating country for ASEAN-China relations. ${ }^{5}$ That tenure runs from August 2018 to August 2021, in a nice correspondence with China's three-year timetable.

The timetable also falls within the six-year presidency of Rodrigo Duterte which runs from June 2016 to June 2022. In view of the length to which Duterte has gone to accommodate China, this is no mere coincidence. For China, although President Xi has abolished the presidential term limits, Premier Li has in all likelihood only one five-year term left. In proclaiming a three-year timetable, he might have wanted to clutch the completion of the COC negotiation as a major accomplishment of his second term in office (2018-23).

China's timetable is a rare demonstration of its commitment to diplomacy and a rules-based order in the South China Sea. Nevertheless, there is widespread scepticism among Chinese experts about its feasibility. The COC negotiation is an extremely complicated and intricate undertaking. Unless China makes major concessions, the three-year timetable may prove to be a mug's game. Leading experts thus caution against unwarranted optimism and advise a need to manage expectations.

In the event of failure, China will still have two fallback positions. First, Premier Li phrased China's expectation carefully as "striving" for a three-year completion. He gave no promise of achieving it within this period, as indeed it was impossible to give such an assurance. Second, Foreign Minister Wang Yi has repeatedly urged ASEAN countries to sweep aside disruption from outside - that is, interventions from "extra-regional countries" such as the United States. Unlike in the past when China was always the butt of ASEAN criticisms for stalling the process, it has now chided certain ASEAN countries for their passivity and rebuked "extra-regional countries" such as the United States for pulling the string behind the scene.

China's timetable is

a rare demonstration of its commitment to diplomacy and a rules-based order in the South China Sea. Nevertheless, there is widespread scepticism among Chinese experts about its feasibility.

\section{China's Negotiation Tactics}

Given its commitment to the three-year timetable, the MFA's public position on its negotiation approach is on consensus and speed. Finding common grounds,

\footnotetext{
${ }^{5}$ Wang Yi, "Gongtong chengdan zeren, weihu Nanhai heping wending" (Jointly Undertake Responsibility to Safeguard Peace and Stability in the South China Sea), 29 October 2018, Manila, $<$ https://www.fmprc.gov.cn/web/wjbzhd/t1607963.shtml> (accessed 19 February 2019).
} 
proceeding from easy to difficult issues and decision-making by consensus are touted as the hallmarks of China's negotiation approach. Foreign Minister Wang Yi declared an "open attitude" in October 2018, stating that China is open to all kinds of constructive suggestions about the contents of the COC and will try to reach common grounds with ASEAN countries to the maximum extent possible.

There is also a new openness to a legally binding COC. China has long opposed to give the $\mathrm{COC}$ a legally binding character for fear of being embroiled in intricate legal disputes or compelled to take part in dispute settlement mechanisms. Since 2017, however, as the COC process gathered steam, leading Chinese experts have begun to weigh up arguments for a legally binding COC. Wu Shicun, dean of the National Institute for South China Sea Studies and an influential adviser to the government, has gone so far as to contend that China might just as well support a legally binding COC. His reason is that as an upgrade of the DOC, which has been faulted for the lack of enforcement, more legal teeth is a necessary feature of the COC. Besides, China may not be able to resist ASEAN countries' insistence on legality. ${ }^{6}$

Some MFA officials appear to think that the legal nature of the COC is no longer the biggest obstacle in the negotiation; the geographical area of application may present a greater challenge and entail more concessions from China. However, given domestic chasms on the South China Sea, opposition to a legally binding COC remains strong.

In some other areas, China had proceeded from a demanding, if not maximum, bargaining position that was likely to encounter stiff resistance from ASEAN countries. Two proposals tabled for the single draft negotiating text in particular suggest an exclusionist approach to regional order-building.

The proposal on cooperation on the marine economy states that cooperation is to be carried out by the littoral states "and shall not be conducted in cooperation with companies from countries outside the region" (see fn [3], p. 12). Another proposal (see fn [3], p. 13) on military activities states:

The Parties shall establish a notification mechanism on military activities, and to notify each other of major military activities if deemed necessary. The Parties shall not hold joint military exercises with countries from outside the region, unless the parties concerned are notified beforehand and express no objection.

These two proposals, in the economic and military spheres respectively, betray an intention to exclude "extra-regional countries" from two vital areas of activity in the South China Sea. It inadvertently serves to corroborate the already widespread apprehension that China seeks dominance or hegemony in the region.

\footnotetext{
${ }^{6} \mathrm{Wu}$ Shicun, "Cong 'zhunze' xiang nanhai 'zhixu' maijin" (From "Code of Conduct" to "Order" in the South China Sea), Global Times, 20 November 2017, <http://opinion.huanqiu.com/ hqpl/2017-11/11385282.html> (accessed 19 February 2019).
} 
In tabling these proposals, Beijing may have already committed a tactical error, adding suspicion of Chinese hegemony. China's positions are unlikely to be accepted by ASEAN countries, which will not unreasonably see them as impinging too much on their sovereign rights to decide on major national policies. Nevertheless, many experts urge Beijing to take a firm stand on these exclusionist positions, especially when it comes to cooperation in disputed areas.

One scholar (see fn [2]) suggested establishing an observer mechanism based on the principle of "exclusionist openness", a curious oxymoron. "Extra-regional countries" may be granted an observer status if they agree to a set of principles China deems essential. These are familiar ones that disputes must be resolved through negotiation by claimant states, that observer countries should not intervene in territorial disputes and maritime jurisdiction, and that they should not undertake provocative military activities in the disputed areas. This mechanism evidently aims to bind observer countries and shut them out of the disputes management and settlement process.

The same scholar also favours a China-led monitoring not dispute settlement-mechanism that shunt aside ASEAN-centred dispute settlement mechanisms. These mechanisms, including the High Council provided for by the Treaty of Amity and Cooperation (TAC), are said to be ineffective even for settling disputes among ASEAN states; they are consequently even less likely to work in the COC where disputes with China is on the front burner.

However, the more important reason is that ASEANcentred mechanisms are an invitation to intervention by "extra-regional forces" such as the United States and Japan, both signatories to the TAC. The mechanisms for monitoring the implementation of the COC must shun the influence of these countries and give China a controlling role. The intention for China to dominate the workings of the $\mathrm{COC}$ - and thus a big part of the new institutional structure in the South China Sea-cannot be clearer.

...ASEAN-centred

mechanisms are

an invitation to

intervention by

"extra-regional

forces" such as

the United States

and Japan, both

signatories to the

TAC.

\section{Balancing Stability and Rights}

China's new resolve in COC negotiation is in the first instance a tactical response to the July 2016 release of the Philippines versus China arbitration ruling. By leading a new COC-centred regional diplomacy, Beijing hopes to counteract the impact of the ruling, reduce regional tension and promote cooperation around the BRI.

More broadly, COC activism was meant to preserve regional stability, one of the two goals of China's larger strategy towards the South China Sea, the other 
being safeguarding rights. However, it is not an instance of one-sided prioritisation of stability over rights since stability-inducing diplomacy can also help China consolidate strategic gains made by island-building. In this sense, it signals a shift in China's strategy towards achieving a dynamic balancing between stability and rights, rather than driving single-mindedly or lopsidedly for either stability or rights.

The goal of maintaining stability helps to explain why China insists on the $\mathrm{COC}$ as a mechanism for building confidence, managing incidents and facilitating cooperation rather than one for settling territorial disputes or delimiting maritime interests. This position suggests a norms-based approach to regional order-building and is not in itself unreasonable.

The three-year timetable is a demonstration of its commitment to the process. Of note is its new openness to a legally binding COC even though domestic opposition remains strong. At the same time, however, China has adopted a demanding bargaining tactic by attempting to exclude "extra-regional countries" from important regional economic and military matters, thus betraying an exclusionist approach to regional order-building.

Whether the COC negotiation can be completed in three years will depend very much on Beijing's ability to reconcile these conflicting impulses, as well as on the commitment and flexibility of ASEAN countries. 目 